\title{
Genistein alters coagulation gene expression in ovariectomised rats treated with phytoestrogens
}

\author{
Lynne A. Kelly'; John J. O'Leary²; Dana Seidlova-Wuttke ${ }^{3}$; Wolfgang Wuttke ${ }^{3}$; Lucy A. Norris ${ }^{1}$
}

${ }^{1}$ Coagulation Research Laboratory, Dept of Obstetrics and Gynaecology, Trinity Centre for Health Sciences, St. James Hospital, Dublin, Ireland; ${ }^{2}$ Dept of Pathology, Trinity Centre for Health Sciences, St. James Hospital, Dublin, Ireland; ${ }^{3}$ Department of Endocrinology, University Medical Center, Göttingen, Göttingen, Germany

\begin{abstract}
Summary
Recent data has shown that hormone therapy (HT) increases the risk of cardiovascular and thromboembolic disease, particularly in users of oral HT. Phytoestrogens are popular alternatives to oestrogen therapy; however, their effects on cardiovascular risk are unknown. We investigated the effect of the phytoestrogen, genistein on the expression of genes and proteins from the haemostatic system in the liver in an ovariectomised rat model. Fifty-nine virgin female Sprague-Dawley rats were fed with soy-free chow supplemented with $17 \beta$ estradiol (E2) (daily uptake 0.19 or $0.75 \mathrm{mg} / \mathrm{kg}$ body weight), or genistein (daily uptake 6 or $60 \mathrm{mg} / \mathrm{kg}$ body weight), for three months and compared to soy-free control rats. Gene expression of prothrombin, factor VII, fibrinogen alpha and fibrinogen beta was increased with E2 and genistein compared to the soy-free control group $(p<0.001)$. Genistein increased factor VII significantly more than E2 $(p<0.005)$. Plasminogen mRNA
\end{abstract}

was increased in both treatment groups compared to the soy-free control, with genistein expression significantly higher than E2 $(p<0.001)$. Tissue plasminogen inhibitor (tPA), plasminogen activator inhibitor-1 (PAI-1) and C-reactive protein (CRP) expression were also increased in both groups relative the soy-free control. Results of protein analysis largely concurred with those of the mRNA. Oestrogen receptor $\beta$ (ER $\beta$ ) was undetected while oestrogen receptor $\alpha(E R \alpha)$ was detected in each sample group. Genistein can increase the expression of coagulation and fibrinolytic genes. This effect was similar and in some cases higher than $17 \beta$ estradiol. These results suggest that genistein may not be neutral with respect to the haemostatic system.

\section{Keywords}

Haemostasis, phytoestrogen, menopause, thrombosis

\section{Correspondence to:}

L. A. Norris

Coagulation Research Laboratory

Dept. of Obstetrics and Gynaecology

Trinity Centre for Health Sciences, St. James's Hospital

Dublin 8, Ireland

Fax: + 35314531888

E-mail: Inorris@tcd.ie
Financial support:

This study was supported by the Health Research Board of Ireland.

Received: March 29, 2010

Accepted after major revision: July 26, 2010

Prepublished online: September 13, 2010

doi:10.1160/TH10-03-0201

Thromb Haemost 2010; 104:

\section{Introduction}

Cardiovascular disease (CVD) is responsible for 54\% of all deaths in women across Europe (1). The incidence of CVD increases for women with the decline in the natural hormone estrogen at menopause leading to the assumption that the replacement of estrogen in post-menopausal women would be beneficial.

However, results from primary and secondary prevention studies showed that the overall risks of combined HT exceeded the potential benefits and that the use of estrogen-only HT provided no overall protection (2-4). In addition, an increase in the incidence of venous thrombosis (VT) in users of HT was reported (4-5).

Following publication of this data, interest has grown in alternative therapies for post-menopausal women, in particular phytoestrogens. Phytoestrogens are a group of naturally occurring substances produced from plants with weak estrogenic and antiestrogenic activity (6). The lower incidence of CVD in Asian women compared to Western populations is partially believed to be due to their high dietary intake of phytoestrogens in soy foods (7). One of the major soy containing constituents, the isoflavone, genistein, has been reported to be beneficial with respect to cardiovascular risk (8).

Despite this, the American Heart Association has stated that neither soy protein nor isoflavones are beneficial with regard to cardiovascular health; a conclusion based on the lack of effect on plasma lipids and lipoproteins (9). The early increase in CVD events following initiation of HT would suggest that lipid changes may not be useful in predicting CVD risk in this group and that thrombotic mechanisms may be more important.

Although the aetiology of the increased risk of VT is not understood, our group (10) and others (11) have shown that estradiol used in HT can modulate the inhibitors and activators of the haemostatic system.

Some small studies have shown that genistein taken in the diet or as a dietary supplement has a neutral or antithrombotic effect; however, data is scarce and the quality and amount of genistein consumed varied widely between studies (12-14).

Studies of transdermal HT have shown that the first-pass liver effect is important in mediating the prothrombotic effects of estrogens and estrogen-like compounds possibly by altering expression of key haemostatic proteins which are expressed in the 
liver $(10,15)$. Estrogens regulate gene expression directly through their receptors and indirectly through other genomic and non-genomic pathways. Genistein can also bind both estrogen receptors (ER), with a greater affinity for ER $\beta$; however, binding of genistein will result in a different three-dimensional structure to the occupied receptor which may lead to different effects on transcription (16). In addition genistein is known to interact with a wide variety of genomic and non-genomic pathways which may affect gene expression differently to estrogen (17). In this study, we investigated the molecular effects of genistein on haemostatic gene expression in a rat menopause model. We show that genistein can alter the expression of key coagulation proteases at the gene and protein level suggesting that their effects on the haemostatic system at the molecular level may not be as neutral as originally thought.

\section{Materials and methods}

\section{Animals}

Fifty-nine virgin female Sprague-Dawley rats were raised in the animal facility of University of Gottingen Clinic. Animals were kept in Makrolon ${ }^{\circledR}$ cages (type 4) under a 12-hour light, 12-hour dark cycle at ambient temperature $\left(22-24^{\circ} \mathrm{C}\right)$ with a relative humidity of $50-55 \%$ and free access to water. In order to eliminate exposure to soy derived estrogenic compounds found in regular rodent chow, they were fed with soy-free food (Ssniff Spezialdiaten $\mathrm{GmbH}$, Soest, Germany). At three months (mean body weight 244 $\mathrm{g}$ ), the animals were bilaterally ovariectomised (ovx) under ketamin $(11 \mathrm{mg} /$ animal, Ketavet, Pharmacia\&Upjohn, Erlangen, Germany) and xylazin ( $2.5 \mathrm{mg}$ /animal, Rompun, Fi Bayer, Leverkusen, Germany) anaesthesia.

\section{Treatment}

After ovariectomy, animals were randomised and divided into five treatment groups ( $n=11 / 12$ per experimental group). The control group received soy-free food only (SsniffV1355, $10 \mathrm{~mm}$ pellets). The supplemented chow was prepared by mixing the test substances, $17 \beta$ Estradiol (E2) (E-8515, Sigma-Aldrich, Taufkirchen,

Table 1: Number of animals allocated to each treatment group and dose.

\begin{tabular}{l|l|l}
\hline Treatment & \# animals & $\begin{array}{l}\text { Intake } \\
\text { (mg/kg BW) }\end{array}$ \\
\hline Soy free & 12 & \\
\hline Oral E2 low & 11 & $0.19 \mathrm{mg}$ \\
\hline Oral E2 high & 12 & $0.75 \mathrm{mg}$ \\
\hline Genistein low & 12 & $6 \mathrm{mg}$ \\
\hline Genistein high & 12 & $60 \mathrm{mg}$ \\
\hline
\end{tabular}

Germany) and genistein (Chemos, Regenstauf, Germany) with the soy-free food to homogeneity before the process of pelleting. Concentrations in $1 \mathrm{~kg}$ of food are shown in Table 1 .

All experiments were approved by the Local Ethics Committee (local approval number 509.42502/01-36.03). The E2 doses were chosen to reflect the shift from the physiological into the supraphysiological range of treatment. The low dose of genistein was chosen to reflect the exposure of genistein through a regular Asian diet while the high dose was to chosen to reflect a strong soy supplement intake.

\section{RNA extraction and CDNA synthesis}

Frozen liver sections disrupted and homogenised. The RNA extraction process was carried out using the QIAShreddar (Qiagen, Hilden, Germany) and the RNeasy Total RNA mini kit (Qiagen) according to the manufacturers' instructions. RNA integrity and concentration were assessed using a Nanodrop (ND-1000, NanoDrop Technologies, Wilmington, DE, USA) according to the manufacturers' instructions.

Total RNA was reverse transcribed to single stranded cDNA using the High-Capacity cDNA Archive Kit (Applied Biosystems, Foster City, CA, USA) following the manufacturers protocol and stored at $-80^{\circ} \mathrm{C}$ until use. The final cDNA concentration was $20 \mathrm{ng} / \mu \mathrm{l}$.

\section{Taqman $^{\circledR}$ low-density array (TLDA)}

Gene expression analysis was performed using TaqMan ${ }^{\circledR}$ TLDAs. The panel of assays included in the TLDA format is designed to simultaneously assess gene expression patterns of multiple targets in a micro-fluidic system. Each TLDA contains lyophilised gene expression reagents (primers and probes [FAM-labelled]) in a preconfigured 384-well format. Each of the eight separate loading ports feeds into 48 separate wells, with three well replicates per assay. The genes chosen from the TLDA for the purposes of this study are in Table 2 .

Each loading port was filled with a $100 \mu$ lvolume containing 25 $\mu \mathrm{l}$ cDNA (20 ng/ $\mu \mathrm{l}), 25 \mu \mathrm{l}$ of nuclease free water and $50 \mu \mathrm{l}$ of TaqMan ${ }^{\circledR}$ universal PCR master mix $(2 \mathrm{x})$. After loading, the cards were centrifuged and real-time RT-PCR amplification was performed on an ABI Prism ${ }^{\circledR} 7900$ H.T. Sequence Detection system (Applied Biosystems). Thermal cycling conditions were as follows: 2 minutes (min) at $50^{\circ} \mathrm{C}, 10 \mathrm{~min}$ at $94.5^{\circ} \mathrm{C}$, and for 40 cycles, 30 seconds at $97^{\circ} \mathrm{C}$ and $1 \mathrm{~min}$ at $59.7^{\circ} \mathrm{C}$.

\section{TLDA analysis}

TLDA cards were analysed with relative quantification (RQ) documents and RQ manager software for automated data analysis (Ap- 
plied Biosystems). Expression values were calculated using the comparative threshold cycle $\left(\mathrm{C}_{\mathrm{t}}\right)$ method. Briefly, this technique uses the formula $2^{-\Delta \Delta C_{t}}$ to calculate the expression of target genes normalised to a calibrator (soy-free control). We selected 18 s as the endogenous control.

The threshold cycle $\mathrm{C}_{\mathrm{t}}$ indicates the cycle number by which the amount of amplified target reaches a fixed threshold. The $\mathrm{C}_{t}$ data for all target genes and $18 \mathrm{~s}$ were used to create $\Delta \mathrm{C}_{\mathrm{t}}$ values $\left[\Delta \mathrm{C}_{\mathrm{t}}=\mathrm{C}_{\mathrm{t}}\right.$ (target gene) $\left.-\mathrm{C}_{\mathrm{t}}(18 \mathrm{~s})\right] . \Delta \Delta \mathrm{C}_{\mathrm{t}}$ values were calculated by subtracting the calibrator (soy-free) from the $\Delta \mathrm{C}_{\mathrm{t}}$ value of each target. Relative quantification $(\mathrm{RQ})$ values were calculated using the equation $2^{-\Delta \Delta C_{t}}$.

\section{Protein extraction}

Protein was extracted from $20 \mathrm{mg}$ frozen liver tissue using the Ne$\mathrm{Per}^{\circledR}$ nuclear extraction kit (Pierce) for ER $\alpha$ and T-Per ${ }^{\circledR}$ extraction buffer (Pierce, Rockford, IL, USA) for all other proteins, according to the manufacturer's instructions. Halt ${ }^{\mathrm{TM}}$ Protease inhibitor cocktail (Pierce), 1mM PMSF and $1 \mathrm{mM}$ sodium orthovanadate were added to the reagents (CER1 and NER only) fresh before use. The supernatant was collected and stored at $-80^{\circ} \mathrm{C}$ until further use. Protein concentration was determined using absorbance at $570 \mathrm{~nm}$ (Dynex Technologies, Chantilly, VA, USA)

\section{Immunoblotting}

Samples were prepared for Western blotting by boiling $20 \mu \mathrm{g}$ of protein with $2 \mathrm{X}$ Laemmeli buffer at $80^{\circ} \mathrm{C}$ for $5 \mathrm{~min}$. Samples were loaded on a 10\% SDS gel and ran for $90 \mathrm{~min}$ at $200 \mathrm{~V}$ and $25 \mathrm{~mA}$. The proteins were then blotted onto a nitrocellulose membrane (PROTRAN $^{\circledR}$, Whatman, Dassel, Germany) using a semi-dry transfer system (C.B.S Scientific, Del Mar, CA, USA).

ER $\alpha$ was detected immunologically using an antibody directed against ER $\alpha$ (MC-20, Santa Cruz Biotechnology, Inc, Santa Cruz, CA, USA) at 1:200 dilution and secondary goat anti-rabbit IgG HRP (SC-2004, Santa Cruz Biotechnology) at 1:2,000 dilution. Factor VII was detected using primary FVII antibody (MC-19, Santa Cruz Biotechnology) at 1:200 with donkey anti-goat IgG (SC2020, Santa Cruz Biotechnology) at 1:2,000 dilution as the secondary antibody. Prothrombin was detected immunologically using prothrombin antibody at 1:200 dilution (M-87, Santa Cruz Biotechnology) and goat anti-rabbit as secondary at 1:2,000 dilution (SC2004 Santa Cruz Biotechnology). Immunoreactive bands were visualized against a Blueranger ${ }^{\circledR}$ prestained protein molecular weight marker (Pierce) with Supersignal ${ }^{\circledR}$ West Pico chemiluminescence (Pierce) and developed using Kodak Biomax Light film (Sigma-Aldrich) with developer and fixer chemicals (Agfa, Düsseldorf, Germany).
Table 2: Gene list for the TaqMan ${ }^{\circledR}$ low-density arrays.

\begin{tabular}{l|l}
\hline Ref. Seq. & Gene symbol \\
\hline NM_013151.2 & Plat \\
\hline NM_012620.1 & Serpine1 \\
\hline NM_152846.1 & F7 \\
\hline NM_017096.3 & Crp \\
\hline NM_022924.2 & F2 \\
\hline NM_001008724.1 & Fga \\
\hline NM_020071.2 & Fgb \\
\hline NM_053491.2 & Plg \\
\hline NM_012689.1 & ER $\alpha$ \\
\hline
\end{tabular}

\section{ELISA}

Commercially available enzyme linked immunosorbent assay (ELISA) was used for the determination of rat C-reactive protein (CRP), fibrinogen, tissue plasminogen activator (tPA) and plasminogen activator inhibitor-1 (PAI-1) antigen levels (Patricell, Nottingham, UK). The manufacturer's protocol was adapted for use in tissue extracts. All results were expressed per ml of extracted protein

\section{Statistical analysis}

Statistical analysis was performed using SPSS ${ }^{\oplus}$ (version 16.0). Unpaired t-tests were used to compare changes between each group. $\mathrm{P}<0.05$ was considered significant.

\section{Results}

\section{Effect of genistein on coagulation gene expression}

Prothrombin mRNA expression ( Fig. 1A) was significantly increased with all four treatment groups compared to the soy-free control group $(p<0.001)$. A four-fold increase in expression was found with both genistein groups which was significantly higher than in the E2-treated groups $(\mathrm{p}<0.001)$. Similarly factor VII expression (Fig. 1B) was significantly increased by both E2 low and high doses and also by both doses of genistein $(\mathrm{p}<0.001)$. Highest levels of expression were found in the genistein low-dose group which was significant compared with E2 low-dose group $(\mathrm{p}<0.005)$.

The mRNA expression levels of both fibrinogen $\alpha$ and $\beta$ (Fig. $1 C, D)$ were also increased following treatment with each dose of E2 and genistein with no difference between treatment groups. For fibrinogen- $\beta$, levels were increased two- to three-fold compared with soy-free controls $(\mathrm{p}<0.01)$; with a slightly greater increase found for fibrinogen $-\alpha(p<0.001)$ 


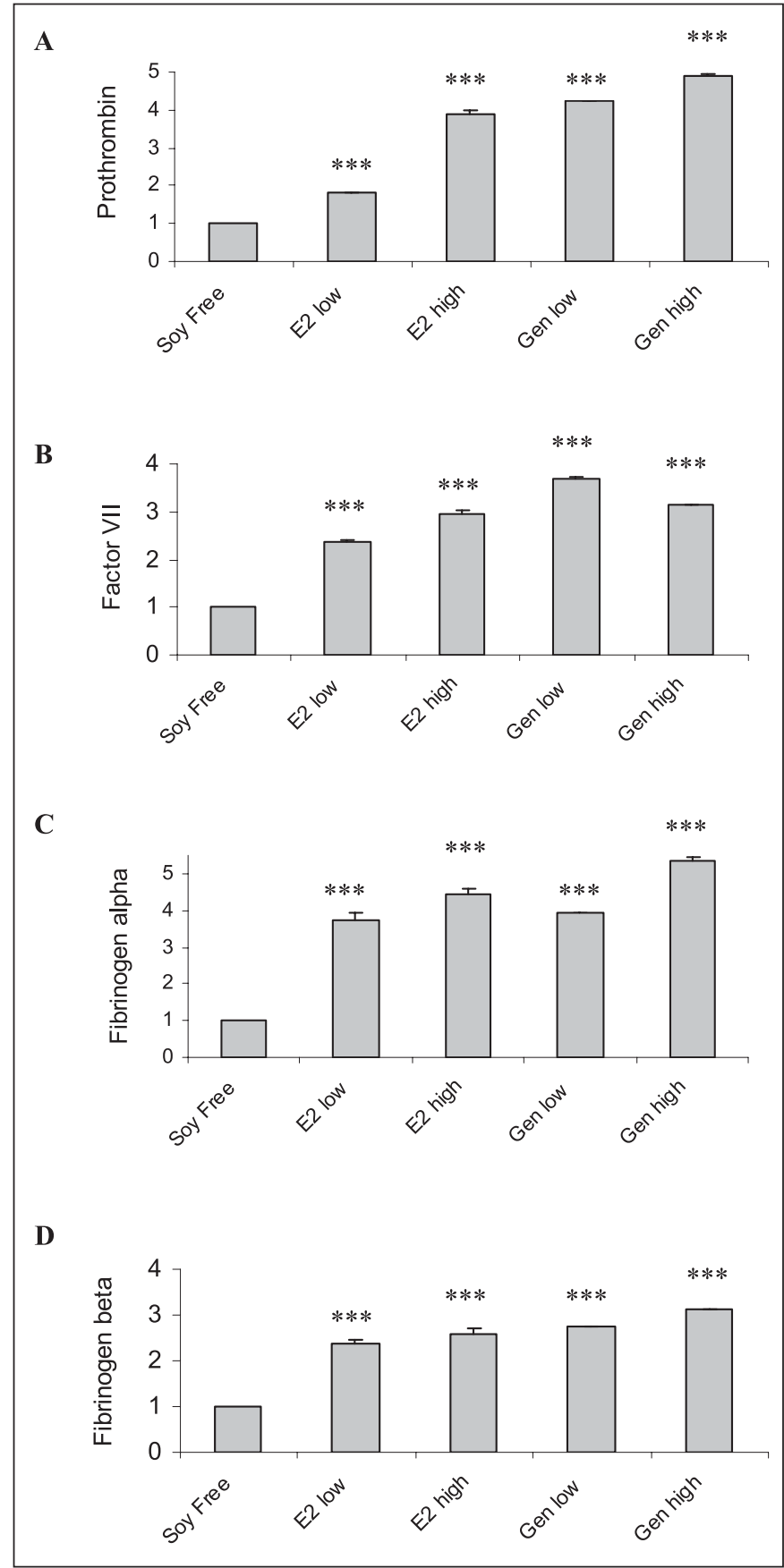

Figure 1: Prothrombin (a), factor VII (b), fibrinogen- $\alpha$ (c) and fibrinogen- $\beta$ (d) mRNA fold change expression in liver tissue of rats fed with soy-free food supplemented with $4.3 \mathrm{mg} 17 \beta$ estradiol (E2 Low), $17.3 \mathrm{mg} 17 \beta$ estradiol (E2 High), $0.1 \mathrm{~g}$ genistein (Gen Low) or $1 \mathrm{~g}$ genistein (Gen High) for three months. Results represent the mean \pm SEM of $11 / 12$ animals in each treatment group. ${ }^{* * *} p<0.001$ compared with soyfree controls.

\section{Effects of E2 and genistein on markers of fibrinolysis}

Plasminogen mRNA expression levels ( Fig. 2A) are increased in all treatment groups $(\mathrm{p}<0.001)$. Genistein at low and high doses

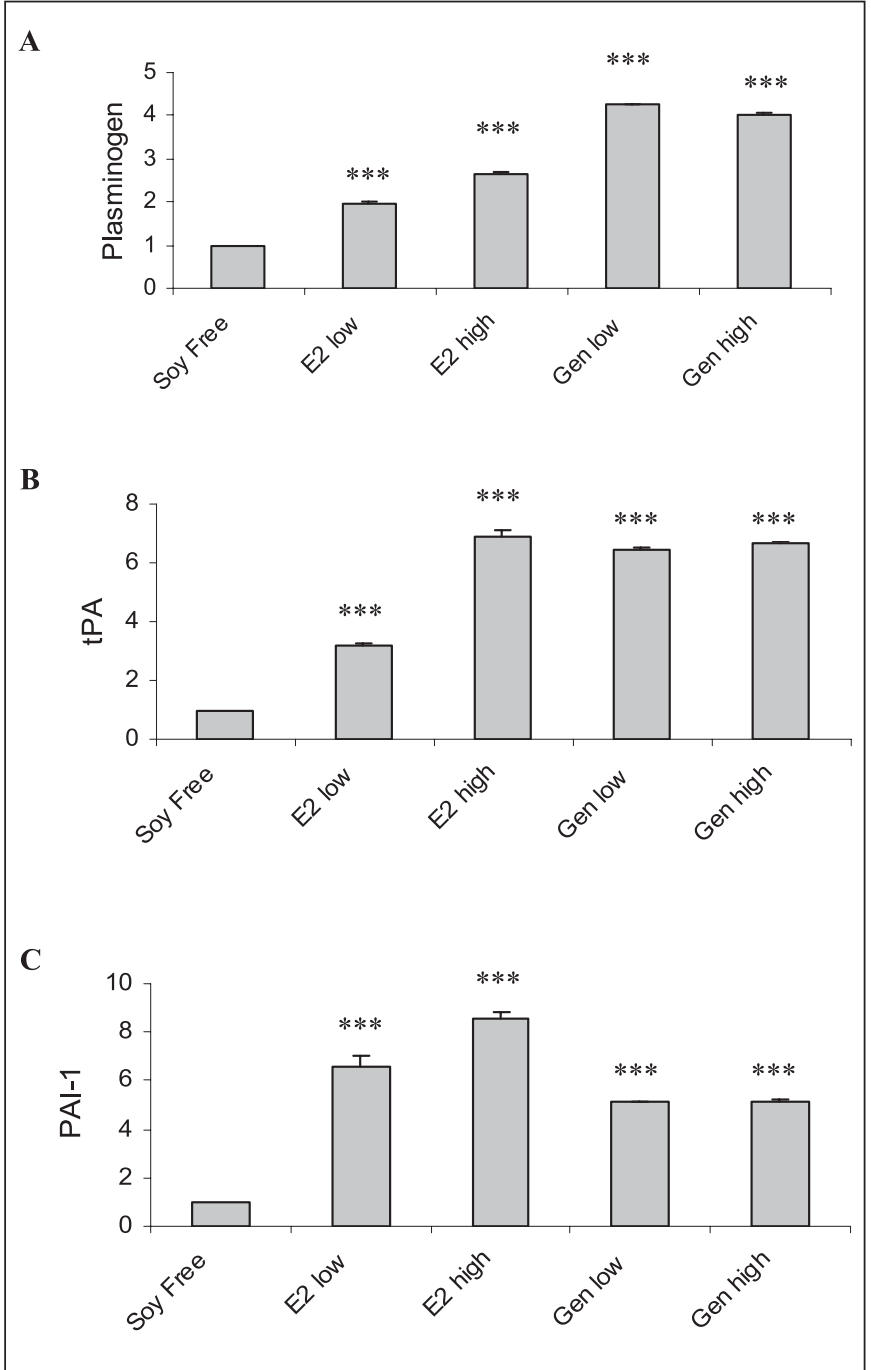

Figure 2: Plasminogen (a), tPA (b) and PAI-1 (c) mRNA fold change expression in liver tissue of rats fed with soy-free food supplemented with $4.3 \mathrm{mg} 17 \beta$ estradiol (E2 Low), $17.3 \mathrm{mg} 17 \beta$ estradiol (E2 High), $0.1 \mathrm{~g}$ genistein (Gen Low) or $1 \mathrm{~g}$ genistein (Gen High) for three months. Results represent the mean \pm SEM of $11 / 12$ animals in each treatment group. ${ }^{* *} p<0.001$ compared with soy-free controls.

have a greater impact on the mRNA levels with significant fold changes of 4 and 3.8, respectively, compared with equivalent E2 treatment groups $(\mathrm{p}<0.001)$. A significant dose dependent increase in $\mathrm{PA} \mathrm{mRNA}$ (Fig. 2B) expression was found in the E2 treatment groups $(p<0.001)$. Both doses of genistein significantly increased the levels of tPA mRNA expression six-fold $(p<0.001)$. This was similar to the levels found in the E2 high-dose group and significantly higher than found in the low E2 $(\mathrm{p}<0.001)$.

In contrast PAI-1 mRNA expression (Fig. $2 \mathrm{C}$ ) was significantly increased six- to eight-fold $(\mathrm{p}<0.001)$ with $\mathrm{E} 2$ while the effect seen is not as marked with genistein treatment, both doses of genistein significantly increased PAI- 1 but with fold changes of $4-5(\mathrm{p}<0.001)$. The difference in fold change between the high dose genistein group and the high dose E2 group was also significant $(\mathrm{p}<0.01)$. 


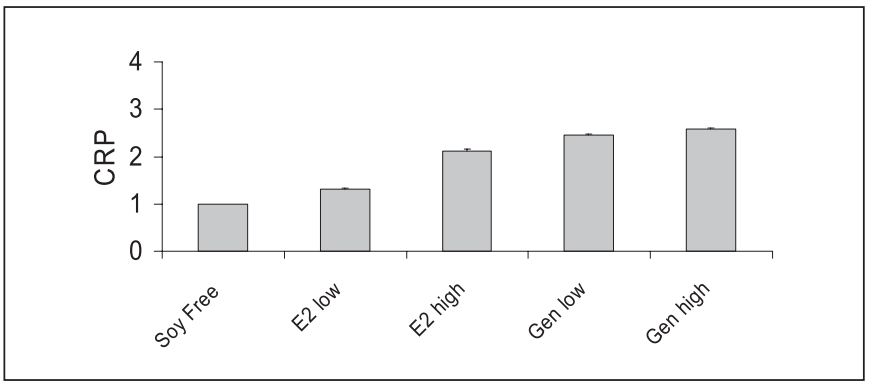

Figure 3: CRP mRNA fold change expression in liver tissue of rats fed with soy-free food supplemented with $4.3 \mathrm{mg} 17 \beta$ estradiol (E2 Low), $17.3 \mathrm{mg} 17 \beta$ estradiol (E2 High), $0.1 \mathrm{~g}$ genistein (Gen Low) or $1 \mathrm{~g}$ genistein (Gen High) for three months. Results represent the mean \pm SEM of $11 / 12$ animals. ${ }^{* * *} p<0.001$ compared with soy-free controls.

\section{Effects of E2 and genistein on CRP}

A small but significant dose-dependent increase in CRP mRNA expression was found in the higher dose E2 group ( Fig. 3). A twofold increase in CRP expression was observed with both doses of genistein $(\mathrm{p}<0.001)$ which was similar to the levels found with E2 high-dose group.

\section{Effects of E2 and genistein on expression of coagulation and fibrinolytic proteins}

For coagulation and fibrinolytic proteins which showed significant increases in mRNA expression, we examined the protein expression in liver tissue homogenates prepared from each treatment group ( Fig. 4). Fibrinogen, CRP and tPA were found in nanogram levels and PAI-1 was virtually non-detectable at picogram levels (Fig. 4A, B, D and C, respectively). Fibrinogen, CRP, PAI-1 and tPA were measured using ELISA. Protein expression largely concurred with mRNA expression results. Higher levels of fibrinogen antigen were found in the genistein-treated group compared to soy-free controls $(\mathrm{p}<0.05)$, levels in the E2-treated group were not significantly different to soy-free controls. Similarly CRP antigen levels were higher in genistein- but not E2-treated animals compared with controls $(\mathrm{p}<0.001)$.

PAI-1 was slightly decreased with E2 treatment and further decreased with genistein. The values obtained were at the limit of assay detection and the changes did not prove significant. E2 treatment decreased the amount of tPA protein expressed whereas genistein made no change to the protein levels in comparison to the soy-free control. The different effects seen between E2 and genistein treatment on $\mathrm{tPA}$ were significant $(\mathrm{p}<0.05)$.

\section{Estrogen receptor mRNA expression in rat liver tissue}

ER $\alpha$ mRNA was detected in rat liver tissue in the soy free, high genistein and higher dose $\mathrm{E} 2$ treatment groups ( Fig. 5). ER $\beta$ was not detected in any of the sample groups.

\section{Western blot analysis of ER $\alpha$}

ER $\alpha$ protein was detected in each of the treatment groups analysed. Similar levels of this receptor were found between groups ( Fig. 6A).
Figure 4: Fibrinogen (a), CRP (b), PAI-1 (c) and TPA (d) antigen as measured with an ELISA adapted for detection in liver tissue. ${ }^{*} p<0.05,{ }^{* *} p<0.01$ compared with soy-free controls.

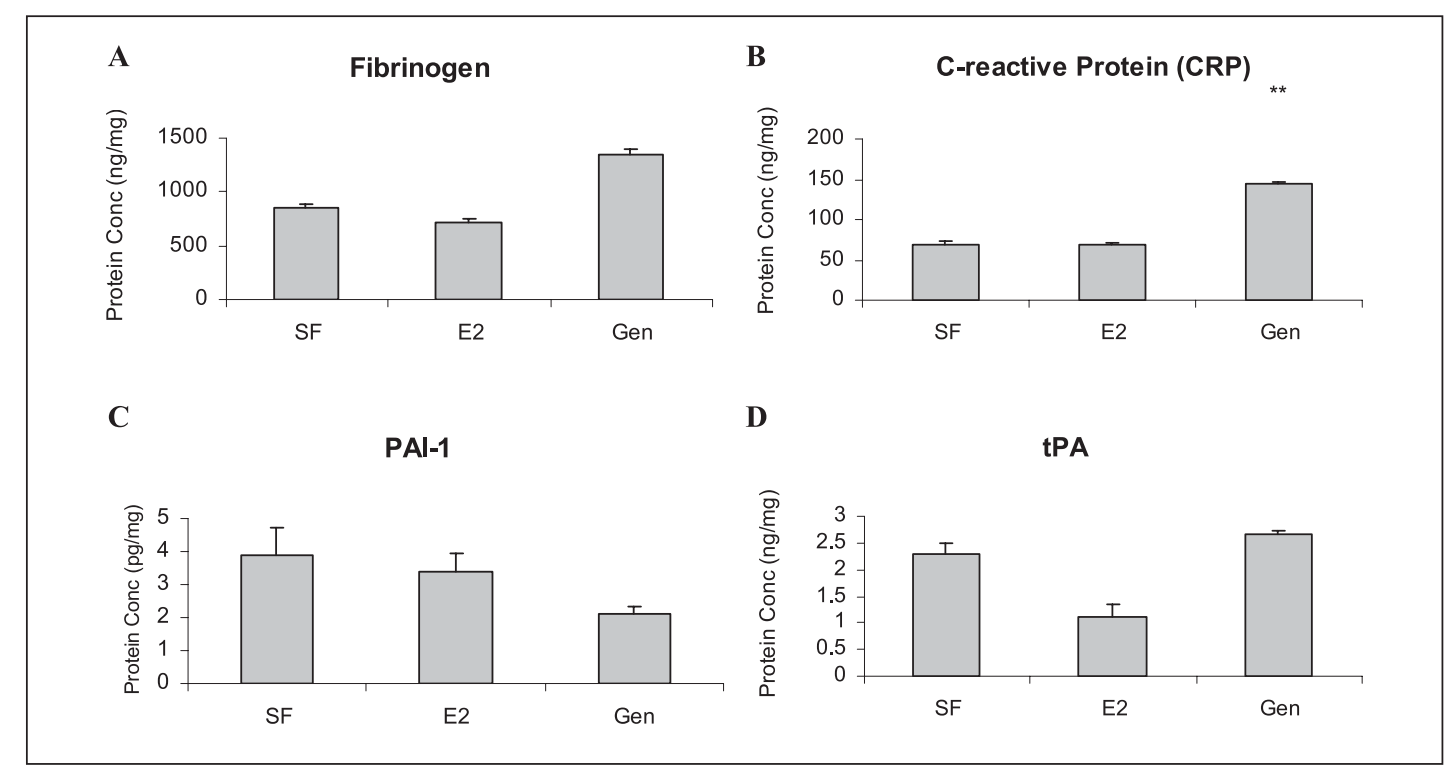




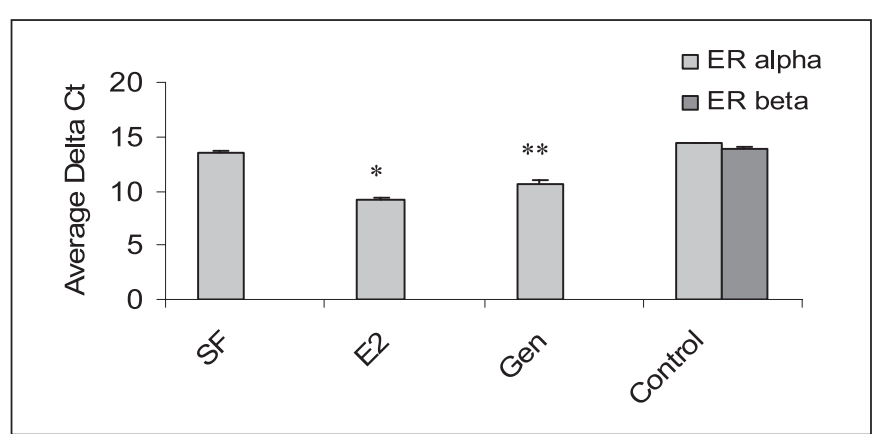

Figure 5: Estrogen receptor expression in liver tissue of rats (12 per group) fed soy-free food supplemented with $17.3 \mathrm{mg} 17 \beta$ estradiol (E2), or $1 \mathrm{~g}$ genistein (Gen) for three months. Control is human ovarian tissue. Results represent the average delta $\mathrm{Ct}$ (target gene-18s). Results represent the mean \pm SEM of $11 / 12$ animals. ${ }^{*} p>0.05{ }^{* *} p>0.01$ compared with soy-free controls.

\section{Western blot analysis of prothrombin and factor VII}

Western blot analysis of prothrombin (Fig. 6B) and factor VII (Fig. $6 \mathrm{C})$ was performed on liver tissue from the soy-free, high-E2 and high-dose genistein groups. Strong prothrombin expression was present in each sample with no difference between the groups. Factor VII expression was also expressed in each sample and a slight

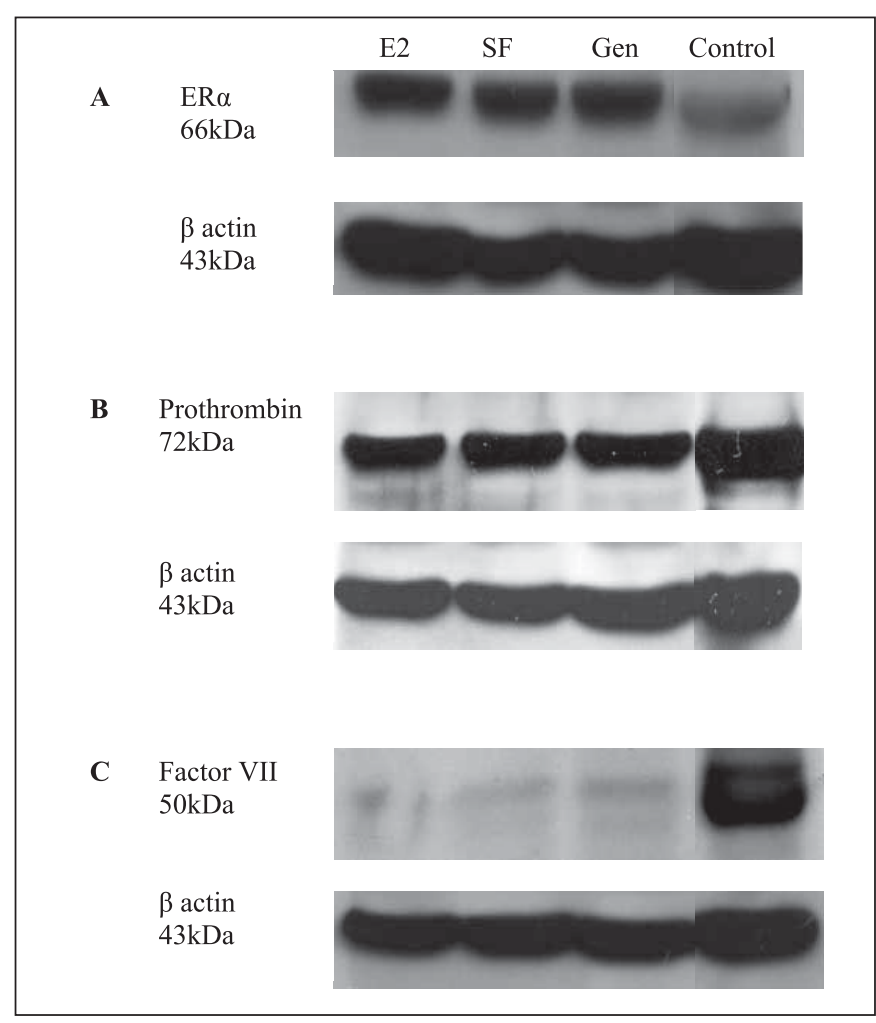

Figure 6: SDS-PAGE and Western blot analysis of ER $\alpha$ (a), factor VII (b) and prothrombin (c) in rat liver tissue. The control for (a) is human ovarian tissue and the control for (b) and (c) is rat liver lysate. increase in factor VII expression was observed in genistein-treated rats compared to soy-free controls.

\section{Discussion}

The results of this study show that in ovariectomised rats, genistein has a marked effect on coagulation and fibrinolytic gene and protein expression in the liver. Three major risk markers for vascular disease, CRP, fibrinogen and factor VII show increased mRNA and protein expression with genistein at levels similar to those found in rats treated with estradiol. Similarly, genes involved in the activation and inhibition of fibrinolysis showed enhanced expression. Recent studies of transdermal HT have shown that the liver plays an important role in mediating the adverse prothrombotic effects of hormone preparations $(10,11)$. By studying the expression of coagulation and fibrinolytic genes in the liver, we can gain an important understanding of the interaction between estrogens and estrogen-like substances and haemostasis at a molecular level.

Relating animal models to humans is difficult but our doses were chosen to reflect real human exposure levels. The estradiol doses reflect a shift from the physiological into the supraphysiological range $(18,19)$. The low dose of genistein represents exposure through the typical Asian diet while the high dose correlates to a strong soy supplement intake (20).

Prothrombin, the precursor to active thrombin, is increased with both treatments in a dose-dependent manner compared to the soy-free control. Increasing prothrombin expression will increase the availability of thrombin following activation. The prothrombin G20210A variant results in increased expression of the prothrombin gene, and is associated with a two- to three-fold increase in venous thrombosis risk in affected individuals (21). This suggests that enhanced prothrombin expression at a molecular level is linked to increased thrombosis risk; therefore the increased prothrombin mRNA expression found in genistein treated rats could lead to increased thrombosis risk in women taking supplements that contain genistein.

Factor VII plays an important role in the initiation of thrombus formation and is a documented risk factor for CVD. Studies have shown that FVII antigen was increased with unopposed estrogen (22) and opposed estrogen (23). At a molecular level, we found increased factor VII mRNA expression in both estradiol- and genistein-treated rats, FVII protein expression was also observed and seemed to be slightly increased in genistein-treated rats. This small increase in protein expression in liver tissue may be reflected in plasma where increased levels of factor VII antigen have been linked to cardiovascular disease risk (24).

Fibrinogen- $\beta$ is an important regulator of synthesis of the fibrinogen molecule and polymorphisms in this gene have been linked to arterial thrombosis (25-26). However debate persists whether this is a direct effect or whether it is secondary to other changes related to the atherosclerotic process. The $\beta$-chain fibrinogen gene contains several regulatory sites including interleukin (IL)-6 responsive elements and hepatic nuclear factor 1 site (27). The IL-6 
sites are considered to be important in mediating raised levels as a result of an acute phase response. The genistein mediated effects observed in our study could be the result of an indirect IL-6 mediated effect or a direct ER-dependent effect. In conflict with these findings, our group and others have found that plasma levels of clottable fibrinogen in post menopausal women taking estrogen is frequently reduced despite evidence of increased fibrin turnover $(11,23,28,29)$. Further work is required to determine the relationship between enhanced fibrinogen expression in the liver and the levels of fibrinogen clotting activity in plasma.

Ovariectomised rats treated with genistein in our study showed an increase in the expression of activators and inhibitors of fibrinolysis. For tPA this increase was similar to that found with highand low-dose estradiol, PAI-1 expression, although increased compared to that found with soy-free animals, was less than was found in estradiol-treated rats. At the protein level, estradiol and genistein treatment did not significantly change tPA or PAI-1 expression, but tPA was significantly higher with genistein compared to estradiol. PAI-1 levels were very low, and it is possible that the ELISA used was not sensitive enough to detect differences in expression in liver tissue and therefore this would not be a conclusive result. Both tPA and PAI-1 antigen levels in plasma are linked with cardiovascular risk; however, both are clustered with other risk factors including triglyceride levels and insulin resistance (30). Active PAI-1 has a short half-life in circulation and cannot be stored in cells. As a result, transcriptional control of PAI-1 plays an important role in regulating tissue and plasma PAI-1 levels.

$\mathrm{CRP}$ is a risk marker for cardiovascular disease and recent studies have identified it as a possible target for use in primary prevention (31). CRP is predominantly synthesised in the liver as an acute-phase reactant and is transcriptionally driven by IL-6 (32). We showed that estradiol and genistein both increase CRP gene expression. Oral estrogen impacts hepatic synthesis of CRP directly and not as a generalised inflammatory response (22). In addition comparative studies of transdermal versus oral estrogen use in post-menopausal women have shown CRP to be increased only following oral use $(33,34)$ without an increase in pro-inflammatory cytokines $(33,35)$. Our results agree with this and show that the phytoestrogen genistein is even more potent in its effect on CRP expression in the rat liver than estradiol.

Our results suggest that genistein, particularly at the higher dose (equivalent to that used in supplements), activates expression of coagulation and fibrinolytic genes in the liver. Genistein binds to both ERs but with greater affinity to $\operatorname{ER} \beta$ (36). The reported beneficial effects of phytoestrogens with respect to cardiovascular risk are generally thought to be mediated through $\operatorname{ER} \beta(16,36,37)$. In our study, we found the expression of ER $\beta$ to be absent in our rat liver tissue, hence genistein in this model is likely to enhance transcription by other mechanisms which may or may not include $\mathrm{ER} \alpha$. Genistein is known to influence a wide variety of other regulatory pathways. These include the ERK/MAP kinase pathway, PPAR mediated transcription and NFKB pathway (38). Genistein can also directly stimulate plasma membrane associated adenylate cyclases leading to increased cAMP levels and activation of cAMPdependent pathways (39). Further work is required to determine which pathways are involved in eliciting the effects we have described above.

Our results appear to conflict with the data on human plasma levels of haemostatic activation which indicate that isoflavones including genistein have no effect on haemostasis (13) or may even decrease the level of some markers of haemostatic activation (12, 14). There are inherent difficulties in controlling soy intake in human studies which explain how, in several reports, the placebo groups show changes in coagulation activation which are not dissimilar to the study group $(13,14)$. In addition some of these studies used a combination of phytoestrogens rather than a pure genistein supplement $(12,13)$.

Coagulation activation is dependent not only on the production of serine proteases from the liver but also on the expression and activation of activators and inhibitors of coagulation from the vascular endothelium. In addition, endothelial damage and inflammatory cytokines will all influence the level of haemostatic activation detected in plasma. A weakness of our study is that we did not measure activation markers in plasma collected from our rats, however given the variability of assays of prothrombin fragment 1.2 and D-dimer, the number of rats in each group would not provide sufficient statistical power to detect a difference between the treatments. A strength of our study is that we have compared genistein treatment not only to soyfree controls but to the effects of rats treated with estradiol which act as a positive control since estradiol is known to be associated with haemostatic activation and increased thrombotic risk.

In conclusion our study shows that the phytoestrogen, genistein, at concentrations found in normal Asian diets and in added dietary supplements, can increase expression of coagulation and

\section{What is known about this topic?}

- Hormone therapy increases the risk of cardiovascular and thromboembolic disease in post-menopausal women.

- This increased risk is thought to be mediated at least in part via haemostatic changes associated with hormone use.

- Studies of transdermal hormone therapy have shown that the liver is important in mediating the pro-thrombotic effects of hormone therapy.

- Phytoestrogens are popular alternatives to post menopausal oestrogen therapy however data on their effects on haemostasis is scarce.

\section{What does this paper add?}

- We show that genistein can increase expression of key coagulation proteases at gene and protein level in a dose-dependent manner

- Genistein taken in the diet or as a supplement post menopause may not be as neutral with respect to the haemostatic system as was originally thought.

- Mutations which result in enhanced expression of coagulation genes, e.g. pro prothrombin G20210A variant, increase thrombotic risk

- In women with thrombophilia, genistein may act synergistically with these mutations to further increase thrombotic risk. 
fibrinolytic genes expressed in the liver to a level that is similar and in some cases higher than is found with estradiol. For many years, phytoestrogens were thought to have clear vasculoprotective effects which were believed to be mediated predominantly via $\operatorname{ER} \beta$ (36). Our results show that in the liver, a tissue shown to be important in mediating the thrombotic effects of hormones in post-menopausal women, phytoestrogens can cause prothrombotic changes in haemostatic gene expression by a mechanism which is not dependent on ER $\beta$. These results suggest that genistein taken in the diet or as a supplement post menopause may not be as neutral with respect to the haemostatic system as was originally thought. This may be particularly important in women with thrombophilia or with other potentially prothrombotic mutations where genistein may act synergistically with the mutation to increase thrombotic risk. Further studies are required to investigate this effect in animal models of thrombosis.

\section{References}

1. European Heart NetworkEuropean Cardiovascular Disease statistics [Press publication] 2008 [cited December 1, 2009]; Available from: www.ehnheart.org

2. Rossouw JE, Anderson GL, Prentice RL, et al. Risks and benefits of estrogen plus progestin in healthy postmenopausal women: principal results From the Women's Health Initiative randomized controlled trial. J Am Med Assoc 2002; 288: 321-333.

3. Hsia J, Langer RD, Manson JE, et al. Conjugated Equine Estrogens and Coronary Heart Disease: The Women's Health Initiative. Arch Intern Med 2006; 166: 357-365.

4. Hulley S, Furberg C, Barrett-Connor E, et al. Noncardiovascular Disease Outcomes During 6.8 Years of Hormone Therapy: Heart and Estrogen/Progestin Replacement Study Follow-up (HERS II). J Am Med Assoc 2002; 288: 58-64.

5. Hulley S, Grady D, Bush T, et al. Randomized trial of estrogen plus progestin for secondary prevention of coronary heart disease in postmenopausal women. Heart and Estrogen/progestin Replacement Study (HERS) Research Group. J Am Med Assoc 1998; 280: 605-613.

6. Andreana LO, Edward JK. Phytoestrogens: a review of the present state of research. Phytotherapy Res 2003; 17: 845-869.

7. Murkies AL, Wilcox G, Davis SR. Clinical review 92: Phytoestrogens. J Clin Endocrinol Metab 1998; 83: 297-303.

8. Atteritano M, Marini H, Minutoli L, et al. Effects of the phytoestrogen genistein on some predictors of cardiovascular risk in osteopenic, postmenopausal women: a two-year randomized, double-blind, placebo-controlled study. J Clin Endocrinol Metab 2007; 92: 3068-3075.

9. Sacks FM, Lichtenstein A, Van Horn L, et al. Soy protein, isoflavones, and cardiovascular health: an American Heart Association Science Advisory for professionals from the Nutrition Committee. Circulation 2006; 113: 1034-1044.

10. Brosnan JF, Sheppard BL, Norris LA. Haemostatic activation in post-menopausal women taking low-dose hormone therapy: less effect with transdermal administration? Thromb Haemost 2007; 97: 558-565.

11. Scarabin PY, Alhenc-Gelas M, Plu-Bureau G, et al. Effects of oral and transdermal estrogen/progesterone regimens on blood coagulation and fibrinolysis in postmenopausal women. A randomized controlled trial. Arterioscler Thromb Vasc Biol 1997; 17: 3071-3078.

12. Rios DRA, Rodrigues ET, Cardoso APZ, et al. Effects of isoflavones on the coagulation and fibrinolytic system of postmenopausal women. Nutrition 2008; 24: $120-126$.

13. Teede HJ, Dalais FS, Kotsopoulos D, et al. Dietary soy containing phytoestrogens does not activate the hemostatic system in postmenopausal women. J Clin Endocrinol Metab 2005; 90: 1936-1941.

14. Trifiletti A, Gaudio A, Lasco A, et al. Haemostatic effects of phytoestrogen genistein in postmenopausal women. Thromb Res 2008; 123: 231-235.

15. Chu MC, Cushman M, Solomon R, et al. Metabolic syndrome in postmenopausal women: the influence of oral or transdermal estradiol on inflammation and coagulation markers. Am J Obstet Gynecol 2008; 199: 526 e1-7.
16. Kuiper GG, Lemmen JG, Carlsson B, et al. Interaction of estrogenic chemicals and phytoestrogens with estrogen receptor beta. Endocrinology 1998; 139: 4252-4263.

17. Dijsselbloem N, Vanden Berghe W, De Naeyer A, et al. Soy isoflavone phyto-pharmaceuticals in interleukin-6 affections. Multi-purpose nutraceuticals at the crossroad of hormone replacement, anti-cancer and anti-inflammatory therapy. Biochem Pharmacol 2004; 68: 1171-1185.

18. Seidlova-Wuttke D, Hesse O, Jarry H, et al. Evidence for selective estrogen receptor modulator activity in a black cohosh (Cimicifuga racemosa) extract: comparison with estradiol-17beta. Eur J Endocrinol 2003; 149: 351-362.

19. Seidlova-Wuttke D, Jarry H, Wuttke W. Pure estrogenic effect of benzophenone-2 (BP2) but not of bisphenol A (BPA) and dibutylphtalate (DBP) in uterus, vagina and bone. Toxicology 2004; 205: 103-112.

20. Doerge DR, Chang HC. Inactivation of thyroid peroxidase by soy isoflavones, in vitro and in vivo. J Chromatogr B Analyt Technol Biomed Life Sci 2002; 777: 269-279.

21. Lane DA, Grant PJ. Role of hemostatic gene polymorphisms in venous and arterial thrombotic disease. Blood 2000; 95: 1517-1532.

22. Lowe GD, Upton MN, Rumley A, et al. Different effects of oral and transdermal hormone replacement therapies on factor IX, APC resistance, t-PA, PAI and C-reactive protein--a cross-sectional population survey. Thromb Haemost 2001; 86: $550-556$

23. Hellgren M, Conard J, Norris L, et al. Cardiovascular risk markers during treatment with estradiol and trimegestone or dydrogesterone. Maturitas 2009; 62: 287-293.

24. Ghaddar HM, Folsom AR, Aleksic N, et al. Correlation of factor VIIa values with factor VII gene polymorphism, fasting and postprandial triglyceride levels, and subclinical carotid atherosclerosis. Circulation 1998; 98: 2815-2821.

25. Kannel WB. Overview of hemostatic factors involved in atherosclerotic cardiovascular disease. Lipids 2005; 40: 1215-1220.

26. Soria JM, Almasy L, Souto JC, et al. A Genome Search for Genetic Determinants That Influence Plasma Fibrinogen Levels. Arterioscler Thromb Vasc Biol 2005; 25 : 1287-1292.

27. Dalmon J, Laurent M, Courtois G. The human beta fibrinogen promoter contains a hepatocyte nuclear factor 1-dependent interleukin-6-responsive element. Mol Cell Biol 1993; 13: 1183-1193.

28. Norris LA, Brosnan J, Bonnar J, et al. Inhibitors and activation markers of the haemostatic system during hormone therapy: a comparative study of oral estradiol (2 $\mathrm{mg}) /$ dydrogesterone and estradiol (2 mg)/ trimegestone. Thromb Haemost 2008; 100: 253-260.

29. Stevenson JC, Oladipo A, Manassiev N, et al. Randomized trial of effect of transdermal continuous combined hormone replacement therapy on cardiovascular risk markers. Br J Haematol 2004; 124: 802-808.

30. Frohlich J, Steiner G. Dyslipidaemia and coagulation defects of insulin resistance. Int J Clin Pract Suppl 2000: 14-22.

31. Pepys MB, Hirschfield GM, Tennent GA, et al. Targeting C-reactive protein for the treatment of cardiovascular disease. Nature 2006; 440: 1217-1221.

32. Devaraj S, Singh U, Jialal I. The Evolving Role of C-Reactive Protein in Atherothrombosis. Clin Chem 2009; 55: 229-238.

33. Decensi A, Omodei U, Robertson C, et al. Effect of transdermal estradiol and oral conjugated estrogen on C-reactive protein in retinoid-placebo trial in healthy women. Circulation 2002; 106: 1224-1228.

34. Shifren JL, Rifai N, Desindes S, et al. A comparison of the short-term effects of oral conjugated equine estrogens versus transdermal estradiol on C-reactive protein, other serum markers of inflammation, and other hepatic proteins in naturally menopausal women. J Clin Endocrinol Metab 2008; 93: 1702-1710.

35. Rachon D, Suchecka-Rachon K, Hak L, et al. Effects of intranasal 17beta-estradiol administration on serum bioactive interleukin- 6 and C-reactive protein levels in healthy postmenopausal women. Menopause 2006; 13: 840-845.

36. McCarty MF. Isoflavones made simple - Genistein's agonist activity for the betatype estrogen receptor mediates their health benefits. Medical Hypotheses 2006; 66: 1093-1114.

37. Altavilla D, Crisafulli A, Marini H, et al. Cardiovascular effects of the phytoestrogen genistein. Curr Med Chem Cardiovasc Hematol Agents 2004; 2: 179-186.

38. Dang ZC. Dose-dependent effects of soy phyto-oestrogen genistein on adipocytes: mechanisms of action. Obes Rev 2009; 10: 342-349.

39. Si H, Liu D. Phytochemical genistein in the regulation of vascular function: new insights. Curr Med Chem 2007; 14: 2581-2589. 